\title{
Outcome in Critically III Cancer Patients: Past and Present ${ }^{\star}$
}

\author{
Prognóstico de Pacientes com Câncer \\ Criticamente Enfermos: Passado e Presente
}

Dominique D. Benoit, $P h D^{1}$, Pieter O. Depuydt, $P h D^{1}$

\section{RESUMO}

JUSTIFICATIVA E OBJETIVOS: Até o final do século passado, havia grande incerteza quanto a propriedade de internar pacientes com câncer em unidades de terapia intensiva (UTI) para medidas de suporte avançado. Contudo, ao longo dos últimos anos, vários centros ao redor do mundo têm reportado aumento significativo da sobrevida de tais pacientes. O objetivo deste estudo foi rever os principais artigos publicados nas duas últimas décadas, com foco na melhoria do prognóstico de pacientes com câncer criticamente enfermos.

CONTEÚDO: Realizou-se uma busca bibliográfica no sistema MedLine - PubMed (www.pubmed.gov) para identificar artigos em linguagem inglesa sobre cuidados intensivos no pacientes com tumores sólidos ou neoplasias hematológicas, com ênfase no prognóstico e no tratamento. Utilizaram-se os seguintes unitermos: cancer, solid tumor, hematologic or hematological malignancies, immunosupression, ICU, ventilation, organ failure, sepsis and infection. Estudos referenciados nos artigos selecionados na busca também foram utilizados.

CONCLUSÕES: O tema será abordado de forma sistematizada. Inicialmente, haverá uma discussão sobre o prognóstico sombrio experimentado por estes pa-

1. Department of Intensive Care Medicine, Medical Unit, Ghent University Hospital, Gent, Belgium.

*Received from Intensive Care Medicine, Medical Unit, Ghent University Hospital, Gent, Belgium.

Presented in January, 26, 2008

Accepted in February, 28, 2008

Address for correspondence:

Dominique D. Benoit, MD

Department of Intensive Care Medicine, Medical Unit

Ghent University Hospital,

De Pintelaan 185, 9000

Gent, Belgium.

E-mail: dominique.benoit@ugent.be

(C)Associação de Medicina Intensiva Brasileira, 2008 cientes no passado. Subseqüentemente, serão discutidos os estudos publicados nos anos recentes sobre a melhoria do prognóstico para os diversos subgrupos de pacientes, a despeito de uma maior gravidade das complicações agudas. Para finalizar, será discutido o papel da ventilação não-invasiva como estratégia inicial de ventilação para estes pacientes.

Unitermos: câncer, prognóstico, Medicina intensiva, ventilação artificial.

\section{SUMMARY}

BACKGROUND AND OBJECTIVES: Until the end of the previous century it remained controversial to admit cancer patients to the ICU for advanced-life-supporting therapy. However, over the past few years several centres over the world have shown that it is possible to achieve a meaningful survival in these patients. The aim of this review is to focus on the improvement in outcome that has been achieved over the past two decades in critically ill cancer patients.

CONTENTS: We performed a MEDLINE search (period of 1980 to November 2007) to identify full-text English language publications on critically ill patients with solid tumors or hematological malignancies with particular interest for the outcome and treatment. Major MESH search terms included; cancer, solid tumor, hematologic or hematological malignancies, immunosupression, ICU, ventilation, organ failure, sepsis and infection. Additional studies were identified through a manual search of citations from retrieved articles.

CONCLUSIONS: In this review, we first focus on the grim prognosis in the past, subsequently we discuss the improvements in outcome over the past few years across subgroups of cancer patients with increasing degree of severity of illness, and finally, we focus on the value of non-invasive ventilation since it is considered the initial ventilatory strategy in these patients.

Key Words: cancer, intensive care, mechanical ventilation, outcome 


\section{INTRODUCTION}

The long-term survival of patients with hematological malignancies has substantially improved over the past two decades. Nowadays, approximately $40 \%$ of the patients with high-grade malignancies such as acute myelogeneous leukemia or non-Hodgkin lymphoma survive for more than 5 years and it is estimated that nearly $30 \%$ of these patients can be cured ${ }^{1}$. Although low-grade hematological malignancies remain incurable, half of the patients will survive for more than 4 years and survival for more than 8 to 10 years is not exceptional in diseases such as chronic lymphocytic leukemia or multiple myeloma. Similar improvements in prognosis can be observed in several solid cancers such as in tumors of the breast, head and neck region and the lower gastro-intestinal tract ${ }^{1}$. These advances in outcome have been achieved by earlier detection, particularly in solid tumors, by a better risk stratification of patients due to advances in radiology, immuno-histology and cytogenetics, by the use of new or intensive chemotherapeutic regimens with or without bone marrow or peripheral stem cell rescue and by advances in supportive care. As a drawback however, the therapeutic intensification coupled with longer survival time has led to an increased occurrence of potential life-threatening complications requiring ICU admission in these immunosuppressed patients ${ }^{2,3}$.

\section{OUTCOME IN CRITICALLY ILL CANCER PATIENTS: EVOLUTION OVER THE PAST TWO DECADES}

Despite the substantial improvement in long-term outcome and quality of life that has been observed in cancer patients over the past two decades, now equaling those of non-cancer chronic illness patient populations ${ }^{4,5}$, it remained however, controversial whether severely ill cancer patients should be admitted to the ICU for advanced life-supporting therapy until the end of previous century ${ }^{6,7}$. The high mortality of more than $80 \%$ in patients requiring mechanical ventilation (Table $1)^{8-15}$, increasing to more than $90 \%$ to $95 \%$ in patients developing multiple organ failure or who require renal replacement therapy during ICU stay ${ }^{12,16-18}$, particularly in the transplant setting ${ }^{19-21}$, together with the severe emotional burden endured by these patients and their relatives, and the considerable costs of advanced and prolonged life-supporting therapy ${ }^{13}$ resulted in a general reluctance to admit such patients to the $\mathrm{ICU}^{2,6,7}$.

However, over the past few years, several centres throughout the world have been reporting on increasingly improving survival in critically ill patients with hematological malignancies and solid tumors ${ }^{22-31}$, approaching survival rates reported in general ICU patients ${ }^{32}$. In a case-historical control study ${ }^{22}$, Azoulay et al. reported a four-fold lower risk of death in cancer patients who required mechanical ventilation between 1996 and 1998 as compared with 1990-1995. Although the severity of illness upon ICU admission significantly increa-

Table 1 - Hospital Mortality in Ventilated Cancer Patients; Evolution Over the Past Two Decades ${ }^{a}$

\begin{tabular}{|c|c|c|c|c|}
\hline Authors & $\begin{array}{l}\text { Patients } \\
\text { (n) }\end{array}$ & $\begin{array}{l}\text { Solid Tumours } \\
\text { (n) }\end{array}$ & $\begin{array}{c}\text { Hematologic Malig- } \\
\text { nancies ( } \mathrm{n})\end{array}$ & $\begin{array}{c}\text { Mortality } \\
(\%)\end{array}$ \\
\hline Schuster and Marion ${ }^{8}, 1983$ & 52 & 0 & 52 & 92 \\
\hline Ewer et al. $.{ }^{9}, 1986$ & 46 & 46 & 0 & 91 \\
\hline Peters et al. ${ }^{10}, 1988$ & 116 & 0 & 116 & 82 \\
\hline Brunet $^{12}, 1990$ & 111 & 0 & 111 & 85 \\
\hline Sculier and Markiewicz ${ }^{11}, 1991$ & 64 & 37 & 27 & $80 / 70$ \\
\hline Shapira et al. ${ }^{13}, 1993$ & 54 & 24 & 30 & $75 / 76$ \\
\hline Epner et al. ${ }^{14}, 1996$ & 86 & 0 & 86 & 75 \\
\hline Groeger et al. ${ }^{15}, 1999$ & 782 & 305 & 404 & $63 / 84$ \\
\hline Kress $^{24}, 1999$ & 153 & 95 & 58 & $67^{\mathrm{b}}$ \\
\hline Azoulay et al. ${ }^{22}, 2001$ & 237 & 68 & 169 & $76 / 71^{c}$ \\
\hline Massion et al. ${ }^{26}, 2002$ & 48 & 0 & 48 & 75 \\
\hline Benoit et al. ${ }^{28}, 2003$ & 88 & 0 & 88 & 68 \\
\hline Maschmeyer et al. ${ }^{27}, 2003$ & 189 & 103 & 86 & $73^{b}$ \\
\hline Depuydt et al. $.^{29}, 2004$ & 166 & 0 & 166 & 71 \\
\hline Azoulay et al. ${ }^{30}, 2004$ & 203 & 23 & 180 & $75^{\mathrm{b}}$ \\
\hline Soares et al. ${ }^{31}, 2005$ & 463 & 359 & 104 & $65 / 68$ \\
\hline
\end{tabular}

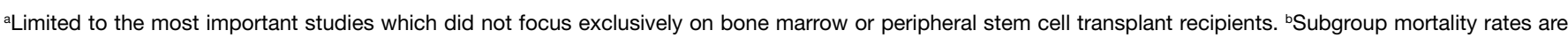
not reported. ${ }^{\circ} 30$ days mortality rates 
sed between these two periods, the hospital mortality decreased from $82 \%$ to $61 \%(p<0.001)$. This was also confirmed in cancer patients with septic shock ${ }^{23}$. The same conclusion can be drawn when focusing on crude mortality rates reported over the past 2 decades in the more severe ill subgroups such as those requiring mechanical ventilation (Table 1), renal replacement therapy or both ${ }^{33-35}$. While most centres reported a mortality of $85 \%-90 \%$ in ventilated cancer patients until the end of previous century, most report a mortality of $65 \%-70 \%$ today. In a recent large prospective study including 463 cancer patients who were ventilated $>24$ hours, Soares et al. ${ }^{31}$ reported a hospital mortality of $64 \%$. Recommendations regarding the duration of mechanical ventilation have also changed over the past 2 decades. Until the end of 1980, most authors recommended to ventilated cancer patients for no longer than 5-7 days because of $100 \%$ mortality ${ }^{8,9}$. However, the duration of mechanical ventilation is no longer reported to be of prognostic importance today ${ }^{22,29-31}$. For instance, of the 112 patients with hematological malignancies ventilated in our centre $>7$ days between 1997 and 2007, $26 \%$ survived to hospital discharge and $20 \%$ were still alive at 6 months (unpublished data). However, the survival of ventilated allogeneic bone marrow or peripheral stem cell transplantation recipients remains particularly poor ${ }^{19-21}$ although some improvement has been achieved $^{36-38}$. Encouraging results have also been obtained in cancer patients requiring renal replacement therapy for acute renal failure, even in case of multiple organ failure or in combination with ventilatory support ${ }^{33-36}$. While renal replacement therapy was unequivocally associated with a $90-95 \%$ ICU mortality in case of multiple organ failure two decades ago ${ }^{12,18}$, Soares et al. ${ }^{31}$ recently reported $65 \%$ six month mortality in patients with one or two associated organ failures and a $93 \%$ six month mortality in case of 3 associated organ failures, again similar to general ICU patients ${ }^{32}$. Moreover, in a study by Benoit et al. comparing the six-month survival between critically ill patients with and without hematological malignancy, the presence of an underlying hematological malignancy was not independently related with six-month survival once accounting for the severity of illness upon ICU admission or the duration of hospitalization prior to admission ${ }^{33}$. Finally, recently two centres reported the survival rates of cancer patients who underwent urgent chemotherapy while being critically ill ${ }^{39,40}$. Although clearly, these patients were highly selected, meaningful long-term survival was observed despite the need for advanced life-supporting therapy during ICU stay in patients with hematological malignancies or chemo-sensible solid tumors at first presentation of their disease, a finding that no one could have been thought of being possible a few years ago.

These improvements in outcome can been attributed to a better selection of patients with respect to their underlying malignancy and subsequent expected longterm prognosis $22,28,31,40$, the increasing use of peripheral blood stem cell transplantation ${ }^{36}$, the availability of better supportive measures in the subgroup of immunocompromised patients such as of non-invasive ventilation $^{22,41}$ and last but not least the advances in the treatment of sepsis and in ICU support in general ${ }^{42,43}$.

\section{PROGNOSTIC INDICATORS: SUBGROUPS WITH A BETTER AND WORSE OUTCOME}

It is clear from the previous data that the presence of an underlying cancer alone can no longer be considered a contra-indication to refer or admit patients to the ICU, even for advanced life-supporting therapy. However, these relative good results should neither be used to justify therapeutic perseverance nor to withhold palliative care in patients who are in a desperate situation. Providing advanced life-supporting therapy to patients with a dismal chance of successful recovery, regardless of whether it is related to an underlying cancer or other severe co-morbidity, is associated with a huge emotional burden for patients, relatives and caregivers as well, and is associated with considerable cost for the society ${ }^{13}$. However, the decision to provide or withhold advance life-supporting therapy remains difficult in an individual patient in daily practice. The complexity of such a decision cannot be replaced by a simple number of prognostic indicators, by a rule of thumb or even by a more complex scoring system ${ }^{44,45}$. Even ICU physicians often dealing with such patients fail to discriminate well between survivors and non-survivors ${ }^{46}$. Nevertheless, a number of prognostic indicators have been identified to guide physicians in their decisionmaking ${ }^{15,16,27-31,44}$. Of course beside these prognostic indicators, the patient's perceived quality of life and the wishes of the patient and/or the relatives should also be taken into account. Advanced care planning and good and honest communication regarding the patient's prognosis between the patient and/or relatives, the attending hemato-oncologist and the ICU physicians upon referral to the ICU is therefore essential. In case of doubt a 3 days therapeutic trial can be tried ${ }^{47}$. As in every patient who is referred to the ICU, the de- 
gree and duration of advanced life-supporting therapy should be in proportion with the expected long-term survival. Of course, the type of cancer and its available treatments, the cancer status and the remaining therapeutic options in case of relapse or active disease are important to take into account. Age has only a minimal impact on the six-month survival in critically cancer patients ${ }^{48}$. The performance status and comorbidity are much more important ${ }^{44,49,50}$ for both the long-term and the short-term survival. The short-term survival, however, will essentially depend upon the number and severity of organ failures and the subsequent need for advanced life-supporting measures such as mechanical ventilation and/or renal replacement therapy on the one hand ${ }^{16,28-35}$, and the reversibility of the organ failure on the other ${ }^{17,51}$. The latter will essentially depend upon the availability of an effective treatment and the time until response to such treatment. Paradoxically, bacterial infection has been found to be associated with a better outcome in several studies, particularly in patients with hematological malignancies and this regardless of the degree of advanced life-supporting therapy $26,28,29,33,41,43,52,53$. It is a serious complication, which is associated with an average mortality of $30 \%$ in patients without pulmonary infiltrates ${ }^{43,53}$, increasing to $65 \%$ in patients with pulmonary infiltrates ${ }^{43,53,54}$ or who require ventilatory support ${ }^{28,29,43,53}$ and up to $75 \%$ in those with multiple organ failure ${ }^{33,53}$, regardless of the microbiological documentation ${ }^{43,53}$. However, it is at least a treatable and potentially more rapidly reversible complication ${ }^{28,29,33,43,53}$ compared to many other complications in cancer patients such as major organ involvement by solid tumor ${ }^{31,49}$ or hematological malignancy ${ }^{40,55}$, invasive pulmonary aspergillosis ${ }^{28-30,33,43,52,53}$, post-transplant related complications $^{38,56}$, or an uncertain diagnosis ${ }^{30,41,43,53}$. In a study by Benoit et al. ${ }^{53}$, patient with hematological malignancies requiring mechanical ventilation because of a documented or clinically suspected bacterial infection had a hospital mortality of $65 \%$ compared to $85 \%$ in those ventilated for other reasons $(p<0.001)$. In another study by the same group in patients requiring renal replacement therapy in combination with ventilatory support for the majority, the mortality in patients with bacterial infection was $74 \%$ compared to $95 \%$ in those without $(p=0.059)^{33}$. Important to note is that the mortality rates in these subgroups of patients are similar to the general ICU patients with severe infection ${ }^{57}$ regardless of the recent administration of chemotherapy ${ }^{43}$.

\section{NONINVASIVE OR INVASIVE MECHANICAL VENTI- LATION?}

Acute respiratory failure is common in critically ill cancer patients, and often necessitates mechanical ventilatory support while the underlying cause is searched for and, if possible, treated ${ }^{29,30}$. Hypoxemic respiratory failure may be due to infectious pneumonia ${ }^{26,28-31,52,53}$, invasion of the underlying malignancy $39,45,51,55$, chemotherapy-related acute lung injury ${ }^{56}$, cardiogenic and noncardiogenic pulmonary edema ${ }^{28-30}$ or diffuse alveolar bleeding ${ }^{56}$, whereas hypercapnic respiratory failure may result from comorbidity such as COPD. Noninvasive mechanical ventilation (NIV) is firmly established as first line treatment in hypercapnic patients ${ }^{58}$. As well, two small randomized controlled trials, one in immunocompromized patients and the other in solid organ recipients, favored NIV over invasive ventilation in hypoxemic respiratory failure, with a very high mortality in the invasively ventilated $\mathrm{arm}^{41,59}$. However, NIV should be used with some caution in hypoxemic cancer patients. It should be kept in mind that the results of NIV in hypoxemic respiratory failure in non-immunocompromized patients without cardiogenic pulmonary edema are conflicting ${ }^{60}$. For example, a recent meta-analysis of the use of NIV in patients with acute respiratory distress syndrome found no benefit associated with NIV ${ }^{61}$. Whereas the cause of hypercapnic respiratory failure is essentially pump failure, mainly due to COPD, the causes of intrinsic lung failure leading to hypoxemic respiratory failure are far more heterogeneous: the success of a NIV trial depends upon the underlying cause, which should be treatable and rapidly reversible. As we discussed above, mortality of acute hypoxemic respiratory failure in hematological patients relates not only to the choice of mechanical ventilation, but to the underlying diagnosis as well ${ }^{29,30,41}$. In the aforementioned study by Hilbert et al. ${ }^{41}$, more patients in the NIV arm had a diagnosis of infectious pneumonia, a potentially reversible condition, and this may in part have biased towards the good outcome in NIV-treated patients. A further caveat to the indiscriminate use of NIV in hypoxemic patients is the high mortality of more than $90 \%$ associated with NIV failure, as observed by Azoulay and Depuydt ${ }^{29,30}$. In conclusion, a judicious trial of NIV should be offered to selected, hemodynamically stable and cooperative hematological patients, especially when the cause of hypoxemia appears to be rapidly reversible. However, patients need to be monitored closely for predictors of NIV failure, such as increasing hypoxemia or acidosis ${ }^{62}$. 


\section{CONCLUSIONS}

Until the end of previous century it remained controversial to refer or admit cancer patients to the ICU. However, over the past decade, several centres over the world have shown that is possible to achieve meaningful outcome in these patients. These relatively good results should, however, not be used to justify therapeutic perseverance or to postpone palliative care in patients who are in a desperate situation. Similarly to any other critically ill patient, the degree and duration of advanced life-supporting therapy provided should be in proportion to the patient's expected long-term survival and quality of life. Honest communication regarding these issues between the caregivers, the patient and the relatives before and upon referral to the ICU as well as during ICU stay is therefore essential.

\section{REFERENCES}

01. Brenner $\mathrm{H}$ - Long-term survival rates of cancer patients achieved by the end of the $20^{\text {th }}$ century: a period analysis. Lancet, 2002;360:1131-1135.

02. Sculier JP, Markiewicz E - Intensive care in anticancer centres: an international inquiry. Support Care Cancer, 1995;3:130-134.

03. Freedman N, Hansen-Flaschen J - Intensive Care for oncology patients: short-term prognosis. UpToDate online 13.1. 2005 http://www.utdol. com/application.

04. Gustafsson I, Brendorp B, Seibaek M et al - Influence of diabetes and diabetes-gender interaction on the risk of death in patients hospitalized with congestive heart failure. J Am Coll Cardiol, 2004;43:771-777.

05. McAlister FA, Ezekowitz J, Tonelli M et al - Renal insufficiency and heart failure: prognostic and therapeutic implications from a prospective cohort study. Circulation, 2004;109:1004-1009.

06. Azoulay E, Pochard F, Chevret S et al - Compliance with triage to intensive care recommendations. Crit Care Med, 2001;29:2132-2136.

07. Groeger JS, Bach PB - Consider saying yes. Crit Care Med, 2003;31:320-321

08. Schuster DP, Marion JM - Precedents for meaningful recovery during treatment in a medical intensive care unit. Outcome in patients with hematologic malignancy. Am J Med, 1983;75:402-408.

09. Ewer MS, Ali MK, Atta MS et al - Outcome of lung cancer patients requiring mechanical ventilation for pulmonary failure. JAMA, 1986;256:3364-3366.

10. Peters SG, Meadows JA $3^{\text {rd }}$, Gracey DR - Outcome of respiratory failure in hematologic malignancy. Chest, 1988;94:99-102.

11. Sculier JP, Markiewicz E - Medical cancer patients and intensive care. Anticancer Res, 1991;11:2171-2174.

12. Brunet F, Lanore JJ, Dhainaut JF et al - Is intensive care justified for patients with haematological malignancies? Intensive Care Med, 1990;16:291-297.

13. Schapira DV, Studnicki J, Bradham DD et al - Intensive care, survival, and expense of treating critically ill cancer patients. JAMA, 1993;269:783-786.

14. Epner DE, White $P$, Krasnoff $M$ et al - Outcome of mechanical ventilation for adults with hematologic malignancy. J Investig Med, 1996;44:254-260.

15. Groeger JS, White P Jr, Nierman DM et al - Outcome for cancer patients requiring mechanical ventilation. J Clin Oncol, 1999;17:991-997.

16. Blot $F$, Guiguet $M$, Nitenberg $G$ et al - Prognostic factors for neutropenic patients in an intensive care unit: respective roles of underlying malignancies and acute organ failures. Eur J Cancer, 1997;33:1031-1037.

17. Guiguet M, Blot F, Escudier B et al - Severity-of-illness scores for neutropenic cancer patients in an intensive care unit: Which is the best predictor? Do multiple assessment times improve the predictive value? Crit Care Med, 1998;26:488-493.
18. Lanore JJ, Brunet F, Pochard $\mathrm{F}$ et al - Hemodialysis for acute renal failure in patients with hematologic malignancies. Crit Care Med, 1991;19:346-351.

19. Crawford SW, Petersen FB - Long-term survival from respiratory failure after marrow transplantation for malignancy. Am Rev Respir Dis, 1992;145:510-514.

20. Rubenfeld GD, Crawford SW - Withdrawing life support from mechanically ventilated recipients of bone marrow transplants: a case for evidence-based guidelines. Ann Intern Med, 1996;125:625-633.

21. Bach PB, Schrag D, Nierman DM et al - Identification of poor prognostic features among patients requiring mechanical ventilation after hematopoietic stem cell transplantation. Blood, 2001;98:3234-3240.

22. Azoulay $\mathrm{E}$, Alberti $\mathrm{C}$, Bornstain $\mathrm{C}$ et al - Improved survival in cancer patients requiring mechanical ventilatory support: impact of noninvasive mechanical ventilatory support. Crit Care Med, 2001;29:519-525.

23. Larche J, Azoulay E, Fieux F et al - Improved survival of critically ill cancer patients with septic shock. Intensive Care Med, 2003;29:1688-1695.

24. Kress J, Christenson J, Pohlman A et al - Outcomes of critically ill cancer patients in an university hospital setting. Am J Respir Crit Care Med, 1999;160:1957-1961.

25. Staudinger T, Stoiser B, Mülner $\mathrm{M}$ et al - Outcome and prognostic factors in critically ill cancer patients admitted to the Intensive Care Unit. Crit Care Med, 2000;28:1322-1328.

26. Massion PB, Dive AM, Doyen $\mathrm{C}$ et al - Prognosis of hematologic malignancies does not predict intensive care unit mortality. Crit Care Med, 2002;30:2260-2270

27. Maschmeyer G, Bertschat FL, Moesta KT et al - Outcome analysis of 189 consecutive cancer patients referred to the intensive care unit as emergencies during a 2-year period. Eur J Cancer, 2003;39:783-792.

28. Benoit DD, Vandewoude $\mathrm{KH}$, Decruyenaere JM et al - Outcome and early prognostic indicators in patients with a hematologic malignancy admitted to the intensive care unit for a life-threatening complication. Crit Care Med, 2003;31:104-112.

29. Depuydt PO, Benoit DD, Vandewoude $\mathrm{K}$ et al - Outcome in noninvasively and invasively ventilated hematologic patients with acute respiratory failure. Chest, 2004;126:1299-1306.

30. Azoulay E, Thiery G, Chevret $\mathrm{S}$ et al - The prognosis of acute respiratory failure in critically ill cancer patients. Medicine, 2004;83:360-370.

31. Soares M, Salluh Jl, Spector $\mathrm{N}$ et al - Characteristics and outcomes of cancer patients requiring mechanical ventilatory support $>24 \mathrm{hrs}$. Crit Care Med, 2005;33:520-526.

32. Ferreira FL, Bota DP, Bross A et al - Serial evaluation of the SOFA score to predict outcome in critically ill patients. JAMA, 2001;286:1754-1758.

33. Benoit DD, Hoste EA, Depuydt PO et al - Outcome in critically ill medical patients treated with renal replacement therapy for acute renal failure: comparison between patients with and those without haematological malignancies. Nephrol Dial Transplant, 2005;20:552-558.

34. Darmon M, Thiery G, Ciroldi M et al - Should dialysis be offered to cancer patients with acute kidney injury? Intensive Care Med, 2007;33:765-772.

35. Soares M, Salluh JI, Carvalho MS et al - Prognosis of critically ill patients with cancer and acute renal dysfunction. J Clin Oncol, 2006;24:4003-4010.

36. Price KJ, Thall PF, Kish SK et al - Prognostic indicators for blood and marrow transplant patients admitted to an intensive care unit. Am J Respir Crit Care Med, 1998;158:876-884.

37. Huaringa AJ, Leyva FJ, Giralt SA et al - Outcome of bone marrow transplantation patients requiring mechanical ventilation. Crit Care Med, 2000;28:1014-1017.

38. Pene F, Aubron C, Azoulay E et al - Outcome of critically ill allogeneic hematopoetic stem-cell transplantation recipients: a reappraisal for indications of organ failure supports. J Clin Oncol, 2006;24:643-649.

39. Darmon M, Thiery G, Ciroldi M et al - Intensive care in patients with newly diagnosed malignancies and a need for cancer chemotherapy. Crit Care Med, 2005;33:2488-2493.

40. Benoit DD, Depuydt PO, Vandewoude KH et al - Outcome in severely ill patients with hematological malignancies who received intravenous chemotherapy in the intensive care unit. Intensive Care Med, 2006;32:93-99.

41. Hilbert G, Gruson D, Vargas F et al - Noninvasive ventilation in immunosupressed patients with pulmonary infiltrates, fever, and acute respiratory failure. N Engl J Med, 2001;344:481-487.

42. Pene F, Percheron S, Lemiale $\mathrm{V}$ et al - Temporal changes in management and outcome of septic shock in patients with malignancies in the inten- 
sive care unit. Crit Care Med, 10.1097/CCM.0B013E318165314B.

43. Vandijck DM, Benoit DD, Depuydt PO et al - Impact of recent intravenous chemotherapy on outcome in severe sepsis and septic shock patients with hematological malignancies. Intensive Care Med, 2008; DOI 10.1007/ s00134-008-1002-2.

44. Groeger JS, Lemeshow S, Price K et al - Multicenter outcome study of cancer patients admitted to the intensive care unit: a probability of mortality model. J Clin Oncol, 1998;16:761-770.

45. Soares M, Fontes F, Dantas J et al - Performance of six severity-of-illness scores in cancer patients requiring admission to the intensive care unit: a prospective observational study. Crit Care, 2004;8:R194-R203.

46. Thiery G, Azoulay E, Darmon M et al - Outcome of cancer patients considered for intensive care unit admission: a hospital-wide prospective study. J Clin Oncol, 2005;23:4406-4413.

47. Azoulay E, Afessa B - The intensive care support for patients with malignancy: do everything that can be done. Intensive Care Med, 2006;32:3-5.

48. Soares M, Carvalho MS, Salluh Jl et al - Effect of age on survival of critically ill patients with cancer. Crit Care Med, 2006;34:715-721.

49. Soares M, Darmon M, Salluh $\mathrm{Jl}$ et al - Prognosis of lung cancer patients with life-threatening complications. Chest, 2007:131:840-846.

50. Soares M, Salluh JI, Toscano L et al - Outcomes and prognostic factors in patients with head and neck cancer and severe acute illnesses. Intensive Care Med, 2007;33:2009-2013.

51. Lecuyer L, Chevret S, Thiery G et al - The ICU trial: a new admission policy for cancer patients requiring mechanical ventilation. Crit Care Med, 2007;35:808-814.

52. Gruson D, Hilbert G, Portel $L$ et al - Severe respiratory failure requiring ICU admission in bone marrow transplant recipients. Eur Respir J, 1999;13:883-887.
53. Benoit DD, Depuydt PO, Peleman RA et al - Documented and clinically suspected bacterial infection precipitating intensive care unit admission in patients with hematological malignancies: impact on outcome. Intensive Care Med, 2005;31:934-942.

54. Carratala J, Roson B, Fernandez-Sevilla A et al - Bacteremic pneumonia in neutropenic patients with cancer: causes, empirical antibiotic therapy, and outcome. Arch Intern Med, 1998;158:868-872.

55. Azoulay E, Fieux F, Moreau D et al - Acute monocytic leukemia presenting as acute respiratory failure. Am J Respire Crit Care Med, 2003;167:1329-1333.

56. Afessa B, Peters SG - Major complications following hematopoetic stem cell transplantations. Semin Respir Crit Care Med, 2006;27:297-309.

57. Alberti C, Brun-Buisson C, Burchardi $\mathrm{H}$ et al - Epidemiology of sepsis and infection in ICU patients from an international multicentre cohort study. Intensive Care Med, 2002;28:108-121.

58. British Thoracic Society Standards of Care Committee: Non-invasive ventilation in acute respiratory failure. Thorax, 2002;57:192-211.

59. Antonelli M, Conti G, Bufi $\mathrm{M}$ et al - Noninvasive ventilation for treatment of acute respiratory failure in patients undergoing solid organ transplantation: a randomized trial. JAMA, 2000;283:235-241.

60. Keenan SP, Sinuff T, Cook DJ et al - Does noninvasive positive pressure ventilation improve outcome in acute hypoxemic failure? A systematic review. Crit Care Med, 2004;32:2516-2523.

61. Agarwal R, Reddy C, Aggarwal AN et al - Is there a role for noninvasive ventilation in acute respiratory distress syndrome? A meta-analysis. Respir Med, 2006;100:2235-2238.

62. Antonelli M, Conti G, Moro ML et al - Predictors of failure of noninvasive positive pressure ventilation in patients with acute hypoxemic respiratory failure: a multi-center study. Intensive Care Med, 2001;27:1718-1728. 